\title{
Hubungan lamanya hemodialisis dengan tingkat depresi pada pasangan hidup pasien gagal ginjal kronik di RSUP Prof. Dr. R. D. Kandou Manado
}

\author{
${ }^{1}$ Vicka V. A. Tartum \\ ${ }^{2}$ Theresia M. D. Kaunang \\ ${ }^{2}$ Christofel Elim \\ ${ }^{2}$ Neni Ekawardani
}

\author{
${ }^{1}$ Kandidat Skripsi Fakultas Kedokteran Universitas Sam Ratulangi \\ ${ }^{2}$ Bagian Psikiatri Fakultas Kedokteran Universitas Sam Ratulangi \\ Email: v.tartum_11_261@yahoo.com
}

\begin{abstract}
Depression is a disturbance in the function of human nature associated with feelings of sadness and accompanying symptoms, including changes in sleep patterns and appetite, anhedonia, concentration, psychomotor, fatigue, despair and helplessness. Depression can be obtained by any person, including a person suffering from chronic diseases such as chronic renal disease requiring hemodialysis therapy for life. However, the impact of depression was not only felt by the patient, but also the patient's family, especially spouses of patients would be very easy to get depressed as a result of seeing a loved one suffer, so will affect the support and motivation given to patients, especially in patients undergoing hemodialysis should undergo dialysis for life, so a lot of depression in patients and their families, especially spouses of patients. This study aimed to determine the relationship of the length of hemodialysis with the level of depression in spouses of hemodialysis patients in Prof. Dr. R. D. Kandou Hospital Manado. This was an observational analystical study with a cross sectional design. This study used Hamilton Depression Rating Scale questionaire (HDRS). Data were processed by using SPSS 20.0. The chi-square analysis test showed a p value of 0.105 ( $p>0.05$ ). Conclusion: There was no correlation between the duration of hemodialysis with the degree of depression of chronic kidney failure patient's live spouses.
\end{abstract}

Keywords: depression, chronic kidney disease, hemodialysis, spouse.

\begin{abstract}
Abstrak: Depresi adalah terganggunya fungsi manusia yang berkaitan dengan alam perasaan yang sedih dan gejala penyertanya, termasuk perubahan pada pola tidur dan nafsu makan, anhedonia, konsentrasi, psikomotor, kelelahan rasa putus asa dan tidak berdaya. Depresi bisa didapatkan oleh setiap orang termasuk seseorang yang menderita penyakit kronik seperti penyakit ginjal kronik yang membutuhkan terapi hemodialisis seumur hidup. Dampak depresi pun tidak hanya dirasakan oleh pasien, keluarga pasien terutama pasangan hidup pasien akan sangat mudah mendapatkan depresi akibat melihat orang yang dicintai menderita, sehingga akan memengaruhi dukungan dan motivasi yang akan diberikan kepada pasien, terutama pada pasien yang menjalani hemodialisis yang harus menjalani proses cuci darah seumur hidup, sehingga banyak terjadi depresi pada pasien dan keluarganya terutama pasangan hidup pasien. Penelitian ini bertujuan untuk mengetahui hubungan lamanya hemodialisis dengan tingkat depresi pada pasangan hidup pasien hemodialisis di RSUP Prof. Dr. R. D. Kandou Manado. Metode penelitian yang digunakan ialah analitik observasional dengan pendekatan potong lintang. Penelitian ini menggunakan kuesioner Hamilton Depression Rating Scale (HDRS) dan data diolah menggunakan SPSS 20.0. Uji analisis chi-square mendapatkan nilai $p$ sebesar $0,105$ ( $p>0,05)$. Simpulan: Tidak terdapat hubungan antara lama hemodialisis dengan tingkat depresi pasangan hidup pasien penyakit ginjal kronik.
\end{abstract}

Kata kunci: depresi, penyakit ginjal kronik, hemodialisis, pasangan hidup 
Ginjal adalah organ vital yang memiliki fungsi menyaring darah dari kelebihan garam, cairan, dan produksi sisa agar menjaga komposisi kimiawi dalam tubuh tetap stabil. Penyakit Ginjal Kronik (PGK) merupakan gangguan fungsi ginjal progresif dan tidak dapat sembuh kembali, dan membutuhkan pengganti ginjal. Ketika seseorang menderita PGK, pasien harus mendapatkan terapi seperti hemodialisis, atau transplantasi ginjal. Hemodialisis adalah terapi pengganti faal ginjal yang bertujuan untuk mengeluarkan sisa-sisa protein dan koreksi gangguan keseimbangan air dan elektrolit antara kompartemen darah pasien dengan kompartemen larutan dialisat melalui selaput (membrane) semipermeabel yang bertindak sebagai ginjal buatan.,

Di Jakarta hanya sekitar 3000 pasien PGK yang dapat menikmati pelayanan hemodialisis. Data yang diperoleh di RS Pelni pada Desember 2010, pada pasien yang menjalani terapi hemodialisis, wanita sebanyak 58 orang (42\%) dan pria sebanyak 50 orang (58\%). Beberapa pasien yang tidak ingin menjalani hemodialisis sebab tidak mengetahui fungsi dan tujuan dari hemodialisis serta banyaknya pasien yang menyatakan kurang mampu untuk membayar biaya hemodialisis. Data dari RSUD Arifin Achmad Provinsi Riau pada bulan Mei 2014 berdasarkan kelompok jenis kelamin pada pasien PGK, dimana perempuan memiliki jumlah sebanyak 52\% dan pria sebanyak 48\%. Berdasarkan lama menjalani hemodialisis pada pasien PGK, terbanyak ditemukan pada pasien PGK yang melakukan hemodialisis selama $>12$ bulan yaitu sebanyak 53\%, diikuti dengan lama hemodialisis 6-12 bulan yaitu sebanyak $28 \%$, dan paling sedikit $<5$ bulan sebanyak $19 \%{ }^{3}$

Sungguh sulit bagi seseorang untuk dapat menerima kenyataan bahwa dirinya harus menjalani hemodialisis seumur hidup dengan proses yang berjalan selama 4-5 jam setiap kali tindakan hemodialisis. Hal ini dapat menimbulkan kejenuhan, sehingga dibutuhkan pendamping untuk memotivasi selama menjalani terapi hemodialisis. ${ }^{4}$ Pasien hemodialisis banyak mengalami masalah psikososial, seperti depresi, kecemasan, kesepian, isolasi sosial, putus asa, dan tidak berdaya. Semua hal itu merupakan masalah psikososial yang dapat meningkatkan kebutuhan pasien untuk mendapatkan perawatan holistik, yaitu termasuk perhatian dalam lingkungan dan mendapatkan dukungan dari keluarga. Jika pasien hemodialisis dirawat dan didukung sepenuhnya oleh keluarga, maka masalah psikososial ini bisa dicegah atau diminimalisir. $^{5}$

Dampak depresi pun tidak hanya dirasakan oleh pasien, keluarga pasien terutama pasangan hidup pasien akan sangat mudah mendapatkan depresi akibat melihat orang yang dicintai menderita, sehingga akan memengaruhi dukungan dan motivasi yang akan diberikan kepada pasien, terutama pada pasien yang menjalani hemodialisis yang harus menjalani proses cuci darah seumur hidup, sehingga banyak terjadi depresi pada pasien dan keluarganya terutama pasangan hidup pasien. ${ }^{6}$ Dukungan keluarga adalah bantuan yang diberikan oleh keluarga terhadap anggota keluarganya yang membutuhkan pertolongan. Bentuk-bentuk dukungan keluarga ini dapat berupa dukungan informasional, instrumental, penghargaan, dan dukungan keluarga secara total. Dukungan keluarga tersebut sangat berpengaruh terhadap kesehatan mental pasien. Penelitian ini bertujuan untuk mendapatkan hubungan antara lama menjalani hemodialisis dengan tingkat depresi pada pasangan hidup pasien hemodialisis di Manado.

\section{METODE PENELITIAN}

Penelitian ini menggunakan jenis penelitian analitik observasional dengan pendekatan potong lintang yang dilaksanakan pada bulan Desember 2014 dan dilakukan di dua unit hemodialisis RSUP Prof. Dr. R. D. Kandou Manado. Cara pemilihan sampel dari penelitian ini dengan menggunakan teknik purposive sampling, dimana pengambilan sampel secara purposive ini didasarkan pada suatu 
pertimbangan yang dibuat peneliti yaitu waktu, tenaga, dana dan berdasarkan sifatsifat atau ciri yang sudah diketahui sebelumnya. Jumlah sampel yang didapat sebanyak 34 orang. Analisis data menggunakan uji statistik Chi-Square melalui program SPSS 20.0, dengan $\alpha$ sebesar $5 \%(0,05)$.

\section{HASIL PENELITIAN}

Hasil penelitian tentang hubungan lama menjalani hemodialisis dengan tingkat depresi pada pasangan hidup pasien dengan penyakit ginjal kronik di RUSP Prof. Dr. R.D. Kandou Manado disajikan dalam bentuk analisis univariat yang mencakup tentang karakteristik jenis kelamin, umur, agama, pendidikan terakhir, pekerjaan, pendapatan, dan diagnosis tingkat depresi sedangkan analisis bivariat mencakup hasil deskriptif tabulasi silang, analisis statistik hubungan lama menjalani hemodialisis dengan tingkat depresi pada pasangan hidup pasien penyakit ginjal kronik di RSUP Prof. Dr. R. D. Kandou Manado.

\section{Analisis Univariat}

Tabel 1. Distribusi Responden Berdasarkan Jenis Kelamin, Umur, Agama, Pendidikan, Pekerjaan, Pendapatan, Diagnosa, Lama HD dan Tingkat Depresi Responden

\begin{tabular}{|c|c|c|c|}
\hline \multicolumn{2}{|c|}{ Variabel } & $\mathrm{n}$ & $\%$ \\
\hline \multirow{3}{*}{ Jenis Kelamin } & Laki-laki & 4 & 11,8 \\
\hline & Perempuan & 30 & 88,2 \\
\hline & Total & 34 & 100 \\
\hline \multirow{5}{*}{ Umur } & $\leq 30$ tahun & 3 & 8,8 \\
\hline & $\overline{3} 1-40$ tahun & 10 & 29,4 \\
\hline & 41-50 tahun & 11 & 32,4 \\
\hline & 50-60 tahun & 10 & 29,4 \\
\hline & Total & 34 & 100 \\
\hline \multirow{4}{*}{ Agama } & Protestan & 30 & 88,2 \\
\hline & Katolik & 1 & 2,9 \\
\hline & Islam & 3 & 8,8 \\
\hline & Total & 34 & 100 \\
\hline \multirow{7}{*}{ Pendidikan } & SD & 2 & 5,9 \\
\hline & SMP & 1 & 2,9 \\
\hline & SMA/SMK & 23 & 67,7 \\
\hline & Diploma & 2 & 5,9 \\
\hline & $\mathrm{S} 1$ & 5 & 14,7 \\
\hline & Pascasarjana & 1 & 2,9 \\
\hline & Total & 34 & 100 \\
\hline
\end{tabular}

\begin{tabular}{clcc} 
& Bekerja & 18 & 52,9 \\
Pekerjaan & Tidak Bekerja & 16 & 47,1 \\
& Total & 34 & 100 \\
& <Rp. 500.000 & 16 & 47,1 \\
Pendapatan & >Rp. & 18 & 52,9 \\
& 1.000 .000 & 34 & 100 \\
& Total & & \\
& Penyakit & & \\
& ginjal kronik & & \\
Diagnosis & yang & 34 & 100 \\
& menjalani & & \\
& hemodialysis & & \\
& (CKD on HD) & & \\
& $\leq 6$ bln & 14 & 41,2 \\
Lama HD & $>6$ bln & 20 & 58,8 \\
& Total & 34 & 100 \\
Tingkat & Tidak Depresi & 7 & 20,6 \\
Depresi & Depresi & 27 & 79,4 \\
\hline & Total & 34 & 100 \\
\hline
\end{tabular}

Tabel 1 memperlihatkan karakteristik univariat masing-masing variabel penelitian. Hasil analisis data menunjukkan pada karakteristik jenis kelamin, sebagian besar adalah perempuan dengan jumlah 30 responden (88,2\%). Pada karakteristik umur, sebagian besar responden berumur 41-50 tahun dengan jumlah 11 responden (32,4\%). Pada karakteristik agama, sebagian besar responden mempunyai agama kristen protestan dengan jumlah 30 responden (88,2\%). Pada karakteristik pendidikan, sebagian besar responden mempunyai pendidikan SMA/SMK dengan jumlah 23 responden (67,7\%). Pada karakteristik jenis pekerjaan, sebagian besar responden sudah mempunyai pekerjaan dengan jumlah 18 responden (52,9\%). Pada karakteristik pendapatan, sebagian besar responden sudah mempunyai pendapatan $>$ Rp 1 juta dengan jumlah 18 responden (52,9\%). Pada karakteristik diagnosa seluruh responden (100\%) mempunyai diagnosis CKD on HD. Pada karakteristik lama HD, sebagian besar responden mempunyai lama HD $>6$ bulan dengan jumlah 20 responden (58,8\%). Pada karakteristik tingkat depresi, 27 responden (79,4\%) mengalami depresi dan 7 responden $(20,6 \%)$ yang tidak mengalami depresi. 


\section{Analisis Tabulasi Silang}

Berdasarkan Tabel 2 dapat dilihat hasil analisis tabulasi silang, dimana sebagian besar responden perempuan mengalami depresi sebanyak 24 responden (70,6\%). Sebagian besar responden yang berusia 3140 tahun, 41-50 tahun dan > 50 tahun mengalami depresi masing-masing sebanyak 8 responden (23,5\%). Sebagian besar responden yang beragama kristen protestan mengalami depresi sebanyak 16 responden (47,1\%). Sebagian besar responden dengan pendidikan SMA/SMK mengalami depresi sebanyak 22 responden (64,7\%). Sebagian besar responden yang tidak bekerja mengalami depresi sebanyak 14 responden (41,2\%). Sebagian besar responden dengan pendapatan $<$ Rp. 500 ribu mempunyai mengalami depresi sebanyak 14 responden (41,2\%). Seluruh responden dengan diagnosis CKD on $\mathrm{HD}$ sebagian besar mengalami depresi sebanyak 27 responden (79,4\%).

Analisis bivariat untuk melihat korelasi lama hemodialisis dengan tingkat depresi pada pasangan hidup pasien penyakit ginjal di RSUP Prof. Dr. R. D. Kandou Manado, menggunakan uji Chi Square Test dengan menggunakan $\alpha$ sebesar 5\% $(0,05)$ (Tabel $3)$.

Tabel 2. Analisis tabulasi silang

\begin{tabular}{|c|c|c|c|c|c|c|c|}
\hline \multirow{2}{*}{\multicolumn{2}{|c|}{ Variabel }} & \multicolumn{4}{|c|}{ Depresi } & \multirow{2}{*}{\multicolumn{2}{|c|}{ Total }} \\
\hline & & \multicolumn{2}{|c|}{$\begin{array}{c}\text { Tidak } \\
\text { Depresi }\end{array}$} & \multicolumn{2}{|c|}{ Depresi } & & \\
\hline & & $\mathrm{n}$ & $\%$ & $\mathrm{n}$ & $\%$ & $\mathrm{~N}$ & $\%$ \\
\hline \multirow{3}{*}{ Jenis Kelamin } & Laki-laki & 1 & 2,9 & 3 & 8,8 & 4 & 11,8 \\
\hline & Perempuan & 6 & 17,6 & 24 & 70,6 & 30 & 88,2 \\
\hline & Total & 7 & 20,6 & 27 & 79,4 & 34 & 100 \\
\hline \multirow{5}{*}{ Umur } & $\leq 30$ tahun & 0 & 0 & 3 & 8,8 & 3 & 8,8 \\
\hline & $\overline{3} 1-40$ tahun & 2 & 5,9 & 8 & 23,5 & 10 & 29,4 \\
\hline & 41-50 tahun & 3 & 8,8 & 8 & 23,5 & 11 & 32,4 \\
\hline & $>50$ tahun & 2 & 5,9 & 8 & 23,5 & 10 & 29,4 \\
\hline & Total & 7 & 20,6 & 27 & 79,4 & 34 & 100 \\
\hline \multirow{4}{*}{ Agama } & Protestan & 6 & 17,6 & 24 & 70,6 & 30 & 88,2 \\
\hline & Katolik & 0 & 0 & 1 & 2,9 & 1 & 2,9 \\
\hline & Islam & 1 & 2,9 & 2 & 5,9 & 3 & 8,8 \\
\hline & Total & 7 & 20,6 & 27 & 79,4 & 34 & 100 \\
\hline \multirow{7}{*}{ Pendidikan } & SD & 1 & 2,9 & 0 & 0 & 1 & 2,9 \\
\hline & SMP & 1 & 2,9 & 0 & 0 & 1 & 2,9 \\
\hline & SMA/SMK & 2 & 5,9 & 22 & 64,7 & 24 & 70,6 \\
\hline & Diploma & 0 & 0 & 2 & 5,9 & 2 & 5,9 \\
\hline & $\mathrm{S} 1$ & 2 & 5,9 & 3 & 8,8 & 5 & 14,7 \\
\hline & Pascasarjana & 1 & 2,9 & 0 & 0 & 1 & 2,9 \\
\hline & Total & 7 & 20,6 & 27 & 79,4 & 34 & 100 \\
\hline \multirow{3}{*}{ Pekerjaan } & Bekerja & 5 & 14,7 & 13 & 38,2 & 18 & 52,9 \\
\hline & Tidak Bekerja & 2 & 5,9 & 14 & 41,2 & 16 & 47,1 \\
\hline & Total & 7 & 20,6 & 27 & 79,4 & 34 & 100 \\
\hline \multirow{3}{*}{ Pendapatan } & $<$ Rp.500 ribu & 2 & 5,9 & 14 & 41,2 & 16 & 47,1 \\
\hline & >Rp. 1 juta & 5 & 14,7 & 13 & 38,2 & 18 & 52,9 \\
\hline & Total & 7 & 20,6 & 27 & 79,4 & 34 & 100 \\
\hline Diagnosa & CKD on HD & 7 & 20,6 & 27 & 79,4 & 34 & 100 \\
\hline
\end{tabular}

Tabel 3. Analisis Bivariat

\begin{tabular}{|c|c|c|c|c|c|c|c|c|}
\hline \multirow{3}{*}{\multicolumn{2}{|c|}{ Variabel }} & \multicolumn{6}{|c|}{ Depresi } & \multirow{3}{*}{$P$} \\
\hline & & \multicolumn{2}{|c|}{$\begin{array}{c}\text { Tidak } \\
\text { Depresi }\end{array}$} & \multicolumn{2}{|c|}{ Depresi } & \multicolumn{2}{|c|}{ Total } & \\
\hline & & $\mathrm{n}$ & $\%$ & $\mathrm{n}$ & $\%$ & $\mathrm{n}$ & $\%$ & \\
\hline \multirow{3}{*}{$\begin{array}{c}\text { Lama } \\
\text { HD }\end{array}$} & $\leq 6$ bln & 1 & 2,9 & 13 & 38,2 & 14 & 8 & \multirow{2}{*}{0,105} \\
\hline & $>6$ bln & 6 & 17,6 & 14 & 41,2 & 20 & 58,8 & \\
\hline & Total & 7 & 20,6 & 34 & 79,4 & 34 & 100 & \\
\hline
\end{tabular}


Berdasarkan Tabel 3 dapat dilihat bahwa responden yang mempunyai pasangan hidup dengan lama $\mathrm{HD} \leq 6$ bulan sebagian besar mengalami depresi dengan jumlah 13 responden (38,2\%), sedangkan responden yang mempunyai pasangan hidup dengan lama HD > 6 bulan sebagian besar juga mengalami depresi sebanyak 14 responden $(41,2 \%)$.

Hasil uji statistik menggunakan Chi Square Test untuk melihat hubungan lama HD dengan tingkat depresi diperoleh nilai $p$ sebesar 0,105. Dengan menggunakan $\alpha$ sebesar $5 \%(0,05)$, maka $\mathrm{p}=0,105>0,05$, dengan demikian dapat disimpulkan tidak terdapat hubungan antara lama HD dengan tingkat depresi pasangan hidup pasien penyakit ginjal kronik di RSUP Prof. Dr. R.D. Kandou Manado.

\section{BAHASAN}

\section{Karakteristik Responden dan Analisis Bivariat}

Hasil analisis univariat pada variabel jenis kelamin diperoleh sebagian besar responden adalah perempuan yaitu 30 orang $(88,2 \%)$, yang berarti pasien yang menjalani hemodialisis adalah laki-laki. ${ }^{8}$ Posisi perempuan dalam kehidupan rumah tangga adalah ibu rumah tangga. Dengan pekerjaan rutin ibu rumah tangga yang sudah terbiasa dalam mengurus anggota keluarga termasuk suaminya, maka hal ini akan berdampak pada proses pendampingan suaminya sehingga tidak terlalu menimbulkan masalah depresi. ${ }^{9}$ Saat ini, peran wanita telah berkembang menjadi peran ganda sebagai ibu rumah tangga dan wanita karir. Hal ini juga didukung oleh pekerjaan responden yang sebagian besar sudah bekerja yaitu sebanyak 52,9\%. ${ }^{10}$ Hasil analisis umur responden juga menunjukkan bahwa sebagian besar responden sudah berumur lebih dari 30 tahun yang sudah dianggap dewasa dan mengerti tentang kondisi penyakit yang diderita pasangannya. ${ }^{11}$ Perkembangan ini didukung oleh pengetahuan serta pendidikan wanita yang makin maju berkembang. Faktor pendidikan telah mengubah mindset seorang wanita untuk bisa hidup lebih mapan dan lebih maju. ${ }^{12}$ Tujuannya bukan hanya untuk diri sendiri, tapi bisa untuk keluarga dan orang sekitarnya. Faktor yang datangnya dari keluarga inti, khususnya suami juga bisa memotivasi seorang wanita untuk bekerja. Bisa dari faktor ekonomi keluarga, dukungan suami untuk mengizinkan istri bekerja, ataupun dari usia anak yang mulai besar sehingga sang ibu bisa beraktivitas tambahan sebagai wanita karir. ${ }^{13}$ Dengan begitu, wanita juga bisa berkontribusi dalam menambah penghasilan keluarga. ${ }^{10}$ Anggota keluarga khususnya pasangan hidup pasien memerankan hal yang penting dalam kesejahteraan pasien. Mereka tidak boleh dikesampingkan dalam proses penanganan pasien. Perubahan pola kehidupan keluarga mungkin diperlukan untuk memenuhi kebutuhan pasien. Pasien dan keluarga harus saling berbagi tentang perasaan mereka dalam suatu hubungan saling percaya agar dapat menyesuaikan dengan proses adaptasi dari sakit pasien. ${ }^{14}$

Berdasarkan hasil penelitian tingkat depresi paling banyak dialami oleh responden yang berjenis kelamin perempuan sebanyak 24 orang pasien (70,6\%). Penelitian yang dilakukan Galambos dkk di Amerika terdapat depresi pada perempuan sebanyak $21 \%$ dan lakilaki sebanyak $13 \% .{ }^{15}$ Penelitian pada tahun 2014 oleh Amit dkk terdapat depresi pada perempuan sebanyak 57\% dan pada lakilaki sebanyak 35\%. ${ }^{16}$ Hal ini menunjukkan bahwa gejala depresi paling banyak ditemukan pada perempuan dibanding lakilaki. Menurut Brizendine, ketika perempuan menghadapi suatu konflik lebih sering peka terhadap respon psikologis, sedangkan laki-laki lebih peka pada respon fisiologis, sehingga ketika perempuan mendapat suatu tekanan akan lebih mudah mengalami stres yang kemudian bisa berlanjut menjadi depresi. ${ }^{17,} 18$ Pada hasil penelitian ini tingkat depresi paling banyak dialami oleh responden yang berusia 31-40 tahun dan 41-50 tahun masing-masing sebanyak 8 responden. Usia 31-50 tahun sudah termasuk dalam usia dewasa tengah. Menurut Bastable, pada usia dewasa tengah 
banyak orang yang memiliki tingkat kesadaran diri yang telah berkembang dengan baik. Mereka sudah memikirkan yang terbaik bagi keluarga, serta telah memiliki banyak pengalaman hidup. ${ }^{19}$ Menurut Stuart dan Laraia, usia berhubungan dengan pengalaman seseorang dalam menghadapi berbagai jenis stresor. Hal ini bisa dilihat dari hasil penelitian ini, dimana tingkat depresi terbanyak adalah depresi ringan. ${ }^{20}$ Sehingga dapat disimpulkan, usia tersebut sudah bisa untuk memilih kebutuhan dasarnya secara baik dan mampu melakukan tindakan yang bisa memperbaiki kondisinya sendiri.

Hasil penelitian ini ditemukan bahwa tingkat depresi didominasi oleh responden yang beragama Kristen Protestan sebanyak 24 orang responden (70,6\%). Menurut Aurebach dkk, agama atau keyakinan dapat digunakan untuk mengatasi dan beradaptasi dengan keadaan hidup yang membuat depresi. Meskipun ada banyak faktor yang berkontribusi terhadap terjadinya depresi, namun kegagalan untuk mengatasi depresi dalam kehidupan merupakan faktor utama yang mendasar. ${ }^{21}$

Pada hasil penelitian ini, tingkat depresi paling banyak dialami oleh responden dengan tingkat pendidikan yaitu SMA / SMK sebanyak 22 responden (64,7\%). Tingkat pendidikan setara SMA/SMK secara umum sudah termasuk dalam kategori yang baik sehingga responden sudah mampu mengontrol dan membangun tingkat emosi secara sempurna. Notoatmodjo menyatakan bahwa semakin tinggi tingkat pendidikan akan semakin memengaruhi pola pikir seseorang dalam mengambil keputusan. ${ }^{22}$

Dalam penelitian ini didapatkan status pekerjaan responden terbanyak adalah bekerja dan mengalami depresi. Hasil uji statistik menggunakan Chi Square Test untuk melihat hubungan lama HD dengan tingkat depresi diperoleh nilai $p$ sebesar 0,105 . Dengan menggunakan $\alpha$ sebesar 5\% $(0,05)$, maka $p=0,105>0,05$, dengan demikian dapat disimpulkan tidak terdapat hubungan antara lama HD dengan tingkat depresi pasangan hidup pasien penyakit ginjal kronik di RSUP Prof. Dr. R.D. Kandou Manado. Hal ini sejalan dengan penelitian dari Pruchino dkk pada tahun 2009 yang menyatakan bahwa tidak terdapat hubungan antara lamanya menjalani pengobatan hemodialisis, kepuasan pernikahan, lamanya waktu menikah, ras, usia, jenis kelamin, dan gejala penyakit ginjal dengan tingkat depresi. $^{23}$

\section{SIMPULAN}

Berdasarkan hasil dari penelitian dapat diambil kesimpulan bahwa responden yang mempunyai pasangan hidup dengan lama $\mathrm{HD} \geq 6$ bulan sebagian besar mengalami depresi dengan jumlah 14 responden (41,2\%), sedangkan responden yang mempunyai pasangan hidup dengan lama HD $>6$ bulan sebagian besar juga memiliki depresi sebanyak 20 responden (58,8\%), sehingga tidak terdapat hubungan antara lama HD dengan tingkat depresi pasangan hidup pasien penyakit ginjal kronik di RSUP Prof. Dr. R.D. Kandou Manado $(p=0,105)$.

\section{DAFTAR PUSTAKA}

1. Sudoyo AW, Setiyohadi B, Alwi I. Buku ajar ilmu penyakit dalam (5th ed). Jakarta: InternaPublishing, 2010.

2. Istianti YP. Hubungan antara masukan cairan dengan interdialytic weight gains (IDGW) pada pasien chronic kidney disease diunit hemodialisis di RS PKU Muhammadyah Yogyakarta. Jurnal Kesehatan Profesional Islami. 2014:10(1):14-20.

3. Widyastuti R, Butar-Butar WR, Bebasari E. Korelasi lama menjalani hemodialisis dengan indeks massa tubuh pasien gagal ginjal kronik di RSUD Arifin Achmad Provinsi Riau pada bulan Mei tahun 2014. Jom FK. 2014; 1(2):1-14.

4. Tezel A, Karabulutlu E, Sahin O. Depression and perceived social support from family in Turkish patients with chronic renal failure treated by hemodialysis. J Res Med Sci. 2011;16(5):666-75.

5. Ahkari S, Moshki M, Bahrami M. The 
relationship between social support and adherence of dietary and fluids restrictions among hemodialysis patients in Iran. Journal of Caring Science. 2014;3(1):11-9.

6. Saeed Z, Ahmad AM, Shakoor A. Depression in patients on hemodialysis and theire caregiver. Departement of nephrology and psychiatry. 2012;23(5):946-52.

7. Bayoumi MM. Subjective burden on family carers of hemodialysis patients. Open Journal of Nephrology. 2014;4:79-85.

8. Erdley SD. Problem - solving therapy for depressed older hemodialysis patient : a pilot randomized trial. Libraries University of Pennsylvania. 2013;31:1-125.

9. Riaz A, Kamal S, Butt NS. Psychometry analysis of depression, anxiety and stress among women of Wazirabad city. Caspian Journal of Applied Science Research. 2013; 2(10):61-9.

10.Pudrovska T, Karraker A. Gender, job authority, and depression. Journal of Health and Social Behavior. 2014; 55(4):429-41.

11.Jeste PV, Savia GN, Thompson WK. Association between older and more successful aging: critical role of resiliene and depression. Am J Psychiatry. 2013;170:188-196.

12.Montez JK, Zajacova A. Explaining the widening education gap in mortality among U.S white women. Journal of Health and Social behavior. 2013;54(2):165-81.

13.Marshall M, Flaig A. Marriage, children and self-employment earnings: an analysis of self-employed women in the USA. Journal of Family and Economic Issues. 2014;35(3):313-33.

14.McTavish A, Philips C. Transforming the patient experience: bringing to life a patient-and family-centred interprofessional care at Kingston general hospital. Patient Experience Journal. 2014;1(1):50-5.

15.Galambos NL, Leadbeater BJ, Barker ET. Gender differences in and risk factors for depression in adolescence a 4-year longitudinal study. International Journal of Behavioral Development. 2004;28(1):16-25.

16.Gaeeni M, Farahani MA, Seyedfatemi N. Informational support to family members of intensive care unit patien the perspective of families and nurses. Global Journal of Health Sciene. 2014;7(2):8-19.

17.Brizendine L. The female brain. Jakarta: Ufuk press, 2007.

18.Fitriani A, Hidayati N. Kepekaan humor dengan depresi pada remaja ditinjau dari jenis kelamin. Humans. 2012; 9(1):77-89.

19.Bastable BS. Perawat sebagai pendidik: prinsip-prinsip pengajaran dan pembelajaran. Jakarta: EGC, 2002.

20.Stuart GW, Laraia MT. Principles and practice of psychiatry nursing (8th ed). St Louis: Mosby, 2005.

21.Aurebach RP, Abela JRZ, Zhu X. Understanding the role of coping in the development of depressive symptoms: symptom specificity, gender differences, and cross-cultural applicability. British Journal of Clinical Psychology. 2010;49(4): 547-61.

22.Notoatmodjo S. Promosi kesehatan dan ilmu perilaku. Jakarta: Rineka Cipta, 2007.

23.Pruchino RA, Wilson-Genderson $M$, Cartwright FP. Depressive symptoms and marital statisfaction in the context of chronic disease: a longitudinal dyadic analysis. Journal of Family Psychology. 2009;23(4):573-84. 